\title{
Oh Canada meets Scotland the Brave: Identity, Meaning, Culture, and Music Learning in an Intergenerational Canadian-Scottish Pipe Band
}

\author{
Janice Waldron \\ University of Windsor, Canada \\ Kari K. Veblen \\ Western University of Canada
}

First established in Scotland in the 1870s, civilian Scottish Pipe Bands are now a global intergenerational phenomenon. In Canada, they are a diasporic reminder of the 70,000 Scots who emigrated there in the 19th century. Currently, there are more SPBs per capita in Canada than any country outside of Scotland, with an estimated 240 civilian SPBs located from Nova Scotia to Vancouver. Because Canadian SBPs exist entirely in the community, teaching pipes and drums to beginning members of all ages-adults, teenagers, and children-is done within the confines of each local pipe band. Intertwined with how members of Canadian SPBs learn and teach music are issues of identity and meaning, both of particular importance in the Scottish-Canadian diaspora. In this, the first of a four-part qualitative multi-sited case study, we explored music teaching and learning in one Scots-Canadian Pipe Band located in rural Ontario. Research questions included: How do participants teach, learn, and perform SPB music in a Canadian context? How do Web 2.o technologies facilitate music learning in the genre? What place does this music hold in participants' lives? What role does a "sense of community" play? How is the local situated within the global and vice versa? Finally, what practices correspond to formal school music education and what are striking differences to consider?

Keywords: Lifelong music learning, community music, bagpipes, communities of practice, music learning and teaching

(C) Janice Waldron and Kari K. Veblen. 2020. The content of this article is the sole responsibility of the authors. The ACT Journal and the Mayday Group are not liable for any legal actions that may arise involving the article's content, including, but not limited to, copyright infringement. 
$\mathrm{F}$ irst established in Scotland in the 1870s, civilian Scottish Pipe Bands are now a global intergenerational phenomenon. In Canada, they are a diasporic reminder of the 70,000 Scots who emigrated there in the 19th century (Walker 2015). Currently, there are more pipe bands per capita in Canada than any country outside of Scotland, with an estimated 240 bands located from Nova Scotia to Vancouver. Of these, 140 are located in southern Ontario-thus there are more civilian bands in southern Ontario per capita than any other region in Canada.

Scottish Pipe Bands (SPBs) have been extensively documented from ethnomusicological and historical perspectives. This large corpus of work includes the history of the Great Highland Bagpipe (Dickson 2009, Cohen 1975, Emmerson 1971, Gibson 2002, Shears 2008), specific Pipe Band histories (Mantle 2002, Walker 2015), composing SPB music for SPB competitions (Bertoff 1982), how to run a Pipe Band (Lerwick 1980), Pipe Bands as signifiers of "Scottishness" and identity in the Canadian-Scots diaspora (MacDonald 2006, Mari 2007), ethnographies of Canadian Highland Games (Columbus Doyle 2005, Gaudry 2007, Kerr 1994, Loten 1995, MacRae 2001, Mason 2004), learning and teaching piobreach-the Scottish classical solo piping tradition-but which is a different, albeit related, genre from SPB music (Fantone 2010, McKerrell 2011), and the place of SPBs in the CanadianScottish diaspora (Feintuch 2004). There is also readily available via the Web a plethora of information about how individual Scots pipers and Scottish Pipe Bands fared in competitions, Highland Games, and festivals (McKerrell 2011), as well as a cornucopia of easily accessible teaching materials and resources; these include books, user-generated content, social media sites, and bagpipe forums, the latter of which includes discussions about pedagogy from teachers registered as forum member. Missing from this large body of work is research on how people teach and learn bagpipes in SPBs; there is a limited body of anecdotal work on music learning and teaching in civilian Scottish Pipe Bands in Scotland and Northern Ireland (Beaton 2011, Curnow 2013).

Canadian SBPs exist entirely in the community, thus teaching pipes and drums to beginning members of all ages-adults, teenagers, and children-and is done within the confines of each local pipe band (Barr et al, 2005). Intertwined with how members of Canadian SPBs learn and teach music are issues of identity and meaning, both of particular importance in the Scottish-Canadian diaspora.

Waldron, Janice, and Kari K. Veblen. 2020. Oh Canada meets Scotland the Brave: Identity, meaning, culture, and music learning in an intergenerational Canadian-Scottish pipe band. Action, Criticism, and Theory for Music Education 19 (1): 208-44. https://doi.org/10.22176/act19.1.208 
Research on adult and outside-of-school intergenerational music learninggroups with similar populations to Scottish Pipe Bands-is a relatively new field but has emerged to become a significant area of study in music education. Researchers contend that more work is needed in the area, in informal, nonformal, and formal contexts (Coffman 1996, 2002, 2006; Dabback 2007; Kruse 2007; Myers 2007; Veblen 2012, 2018; Waldron 2009). ${ }^{1}$ Over the past decade, a subfield of this research area has appeared: work on informal music learning in online and convergent on and offline music communities, emergent with the rise of the Internet and Web 2.o technologies. ${ }^{2}$ Relevant to this study is research focused on adult music learning and teaching in the related pan-Celtic genres of Irish traditional, Celtic-Canadian, Bluegrass, and Old Time musics, because this body of work examines why, how, and what motivated adults to learn a specific traditional Celtic music using different online/offline contexts, mediums, and modes (Bayley and Waldron 2019, Blanton 2016, Cawley 2013, Waldron and Veblen 2009, Waldron 2017a).

Although Scottish Pipe Band music is a related Celtic music in the pan-Celtic genre, as noted in the previous paragraph, there is little research focused on how members learn and teach music. Moreover, there have been no investigations of the role and use of genre-related online resources such as social media sites, usergenerated content (UGC), and blogs in SPBs. Neither has there been any research done on a "culture of connectivity" among SPBs, nor SPBs as communities of practice (CoPs) or communities of musical practice (CoMPs). 3 Although rooted in a strictly prescribed military tradition dating to the 1500s, pipers have embraced Web 2.o technologies for teaching music; these technologies also sustain a networked "culture of connectivity" in the global SPB community. Further related to but yet to be examined is how a "culture of connectivity" (Van Dijck 2013) creates, sustains, and grows the on and offline and convergent CoP and the CoMP of Canadian SPBs.

This investigation is the first of a five-part qualitative, multi-sited case study whose purpose was twofold: 1) to examine how members of civilian Canadian SPBs learn and teach music in Canadian contexts, and 2) to investigate the interconnected provincial, national, and international online and offline networks that comprise the community of musical practice of Canadian SPBs, including an exploration of its place in and meaning of "Scottishness" to members. Because issues

Waldron, Janice, and Kari K. Veblen. 2020. Oh Canada meets Scotland the Brave: Identity, meaning, culture, and music learning in an intergenerational Canadian-Scottish pipe band. Action, Criticism, and Theory for Music Education 19 (1): 208-44. https://doi.org/10.22176/act19.1.208 
of cultural transmission, meaning, and identity formation are integral to music learning and teaching in Canadian SPBs, we framed this research with Lave and Wenger (1991)/Wenger's community of practice social learning theory (1998, 2009) and the related community of musical practice theory (Barrett 2006, Kenny 2016).

For this first investigation of our five-part multi-sited case study, we explored music teaching and learning in one Scots-Canadian Pipe Band located in rural southwest Ontario-the Paris-Port Dover Pipe Band (PPDPB). Performance, music teaching and learning, competition, social context, and service are mandates for the PPDPB; the band welcomes all interested participants of any age, playing level, race, ethnicity, gender, sexual orientation, and/or cultural background, furnishing supplies, music, uniforms, and free group and private lessons. Offline instruction is supplemented with online music learning resources (MP3s, written notation, and YouTube videos) curated by the PPDSB directors through the group's members-only social media site "MyBand." Over the course of two years, we interviewed band members and observed the PPDSB participating in local, provincial, and international contexts, while keeping in touch with local activities through the band's online communications through MyBand. In the summer of 2018, we observed the band's participation at the Royal Edinburgh Military Tattoo and documented their interactions with other SPBs from around the world.

Research questions included: How do participants teach, learn, and perform SPB music in a Canadian context? What place does this music hold in their lives? What role does a "sense of community" play? Do social media sites, Highland Games, and piping colleges foster an online and offline convergent community of practice among Canadian SPBs? If so, how? What role does competition play? How is the local situated within the global and vice versa? Does learning that happens in one setting inform learning-for example, Highland Games and Piping summer schools, SPB rehearsals, and online piping sites-that occurs in the other(s) and vice versa? If so, how? What are the characteristics of music teaching and learning that occur in formal, nonformal, and informal-on and offline-settings in each community? Is there a "generational divide" of Internet use for music learning between new learners and established players? How is the local and the national situated within the global and vice versa? What implications can be drawn for lifelong learning, music education, community music, and the field of andragogy? Finally,

Waldron, Janice, and Kari K. Veblen. 2020. Oh Canada meets Scotland the Brave: Identity, meaning, culture, and music learning in an intergenerational Canadian-Scottish pipe band. Action, Criticism, and Theory for Music Education 19 (1): 208-44. https://doi.org/10.22176/act19.1.208 
what practices correspond to formal school music education, and what are striking differences to consider?

\section{Historical context}

Between 1825 and 1914, approximately 70,00o Scots left their homeland to settle in Canada (Walker 2015). More Scots emigrated to Ontario and British Columbia than to Nova Scotia; the rest of Canada also gained significant numbers of Scottish newcomers. These new arrivals often named their new settlements after places from home, but more significantly for this study's purposes, Scottish emigrants also replicated the hierarchies, folkways, and institutions familiar from the old country in the new. Key in building community among Scottish emigrants were cultural associations such as Robbie Burns clubs and civilian Scottish Pipe Bands (McNabb 1999). Civilian pipe bands were first established in Scotland in the 1870 , and they quickly emerged thereafter in Canada where sizable Scottish-Canadian diasporas existed. The oldest Canadian-Scottish Pipe Band, the Sons of Scotland (Ottawa), was established in 1896, followed in 1910 by the Ingersoll Pipe Band, and in 1914, the Vancouver Police Band (Walker 2015). Modern civilian SPBs consist of two sections: the pipes, which may have four to twenty pipers, and a drum section composed of at least two snare drummers, a tenor drummer, and a bass drummer (Walker 2015).

\section{Background}

For this first case study, we selected a Pipe Band to investigate based on a number of considerations: 1) the information listed on their websites-specifically, that they valued music learning and community, and 2) that they were affiliated with the Pipers' and Pipe Band Society of Ontario; to compete, bands must be registered with this organization. This eliminated bands that did not have a web presence or were not Pipe Band Society affiliates (these are often called "parade bands" or "beer bands"). For the larger five-part multi-sited case study, we wanted to investigate pipe bands from a variety of urban, suburban, and rural areas. We also decided to begin in Ontario because of the large number of pipe bands in the province and their relative proximity to us in Southwestern Ontario. That way we could observe

Waldron, Janice, and Kari K. Veblen. 2020. Oh Canada meets Scotland the Brave: Identity, meaning, culture, and music learning in an intergenerational Canadian-Scottish pipe band. Action, Criticism, and Theory for Music Education 19 (1): 208-44. https://doi.org/10.22176/act19.1.208 
the participating band multiple times without complicated travel logistics. After looking at numerous websites, the Paris Port Dover Pipe Band jumped out at us for two reasons. First, the home page from their website:

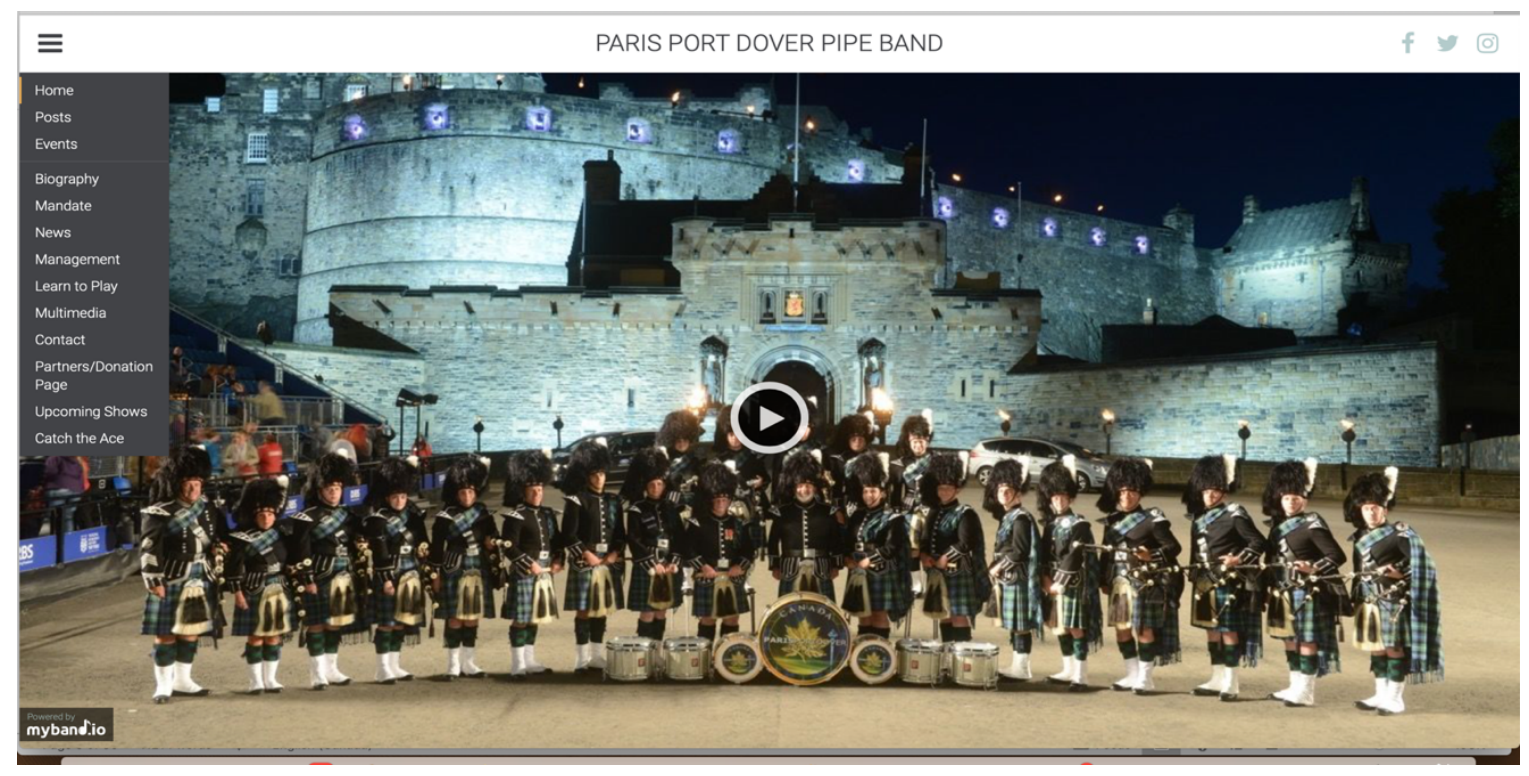

(Retrieved from https://ppdpb.myband.io, September 29, 2019)

It's a striking picture-in front of Edinburgh Castle at the Royal Edinburgh Military Tattoo 4 in 2013-with an inserted YouTube of the band performing at the Air Canada Centre with Sir Paul McCartney. That got our attention, but what sealed the investigative deal for us was this page clearly stating the band's mandate:

Waldron, Janice, and Kari K. Veblen. 2020. Oh Canada meets Scotland the Brave: Identity, meaning, culture, and music learning in an intergenerational Canadian-Scottish pipe band. Action, Criticism, and Theory for Music Education 19 (1): 208-44. https://doi.org/10.22176/act19.1.208 


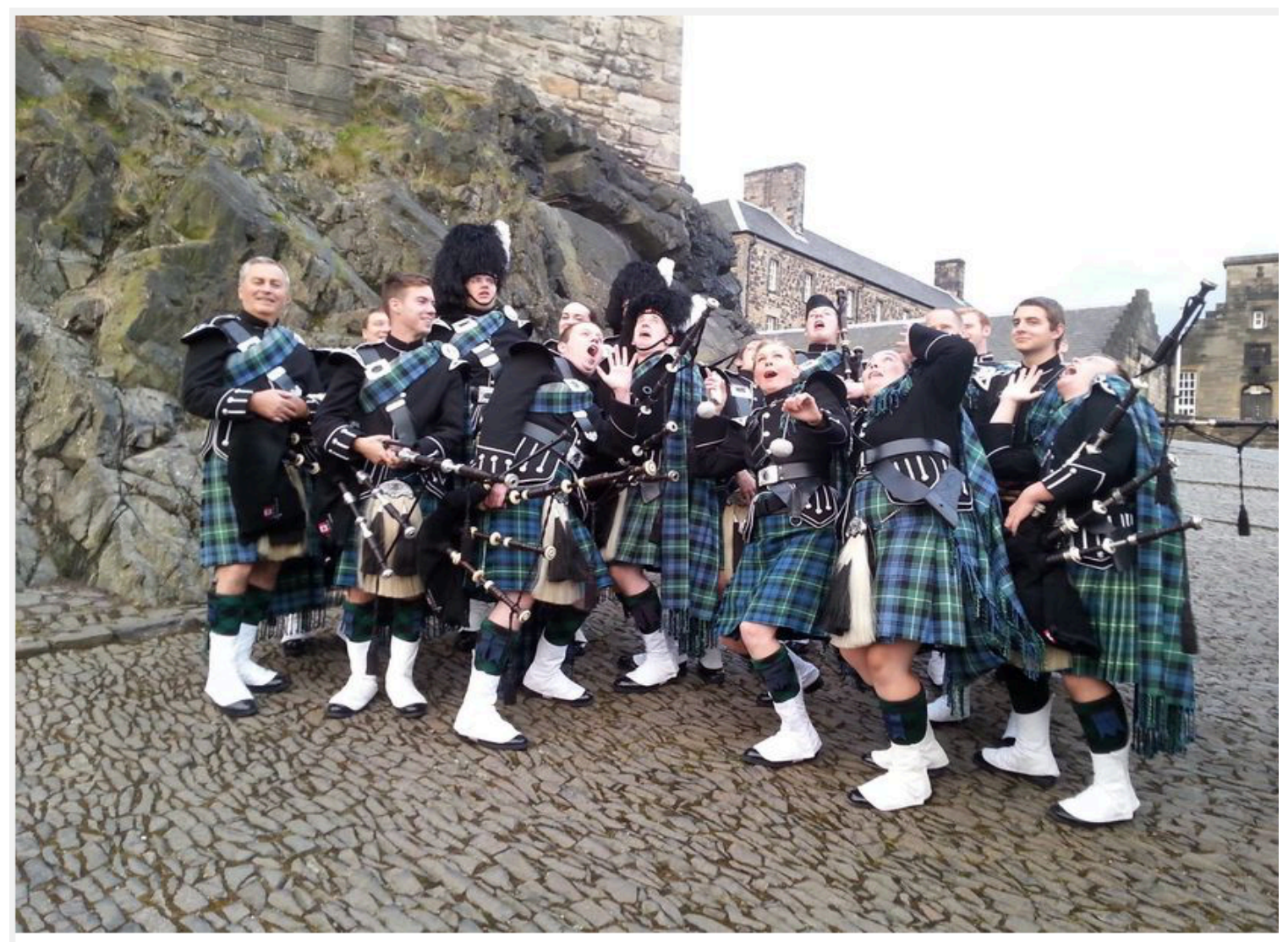

\title{
Mandate
}

\begin{abstract}
Paris Port Dover Pipe Band provides young people of any skill level with instruction in Scottish music and gives them the opportunity to play with the band. We teach youth how to act as ambassadors for Canada, the province of Ontario and our local Brant and Norfolk Counties. We strive to educate on the importance of giving back to local service clubs and non-profit groups by assisting with various ceremonies, memorials, parades and events through band performances.
\end{abstract}

(Retrieved from https://ppdpb.myband.io, September 29, 2019)

They also fit the bill as a small-town Scots-Canadian pipe band. As part of their mandate, no fees are required to join or be in the band; members do, however, buy their chanters and a piping book and buy their pipes when they feel ready for a full set. Reeds, drumsticks, uniforms, and percussion instruments are provided by the band.

Waldron, Janice, and Kari K. Veblen. 2020. Oh Canada meets Scotland the Brave: Identity, meaning, culture, and music learning in an intergenerational Canadian-Scottish pipe band. Action, Criticism, and Theory for Music Education 19 (1): 208-44. https://doi.org/10.22176/act19.1.208 
We contacted band founder and Pipe Major Mr. Gordon Black to ask if he and the band members would be interested in being participants in our study. Fortunately for us, the answer was an enthusiastic "yes." After clearing the study with our respective institutions' Research Ethics Boards, we began data collection in Summer 2017.

\section{Communities of Practice}

Based on the idea that "learning is essentially, a fundamentally social phenomenon, comprised of four components-meaning, practice, community and identity" (Wenger 1998, 3), Wenger's community of practice (CoP) social learning theory (built upon earlier work with Lave in 1991) offers a useful framework for researching convergent on and offline communities like the ones in this study. The primary focus of CoP is on "learning as social participation" $(1998,77)$ that is comprised of four components: meaning, practice, community and identity, integrated with the following three interlocking dimensions:

1. Mutual engagement of the participants.

2. The negotiation of a joint enterprise which is defined by the participants in the very process of pursuing it.

3. A shared repertoire (Wenger 1998, 77).

In 2009, after the continued expansion of networked technologies, social media, and social networking, Wenger, White, and Smith (2009) explicitly addressed how to develop CoPs in online contexts, contending that "because [CoPs] are not defined by place or by personal characteristics but by people's potential to learn together, building and sustaining an online $\mathrm{CoP}$ becomes a powerful way for people to collaborate, share resources, and make new content in the digital age" (11). As on and offline communities continue to merge "place" and "space," CoP theory also serves as a useful research framework for investigations of convergent on and offline music communities like the ones in this study, because, in addition to being a thing that "people do" (Elliott 1995), music is a "thing" that people do together in community regardless of location, be it online, offline, or a mixture of both. Indeed, CoP theory is perhaps the most popular framework employed by those investigating online and convergent community in general (for example, Baym 2010, Coco 2008, Kear 2011, Kimble and Hildreth 2004) and music teaching and learning in

Waldron, Janice, and Kari K. Veblen. 2020. Oh Canada meets Scotland the Brave: Identity, meaning, culture, and music learning in an intergenerational Canadian-Scottish pipe band. Action, Criticism, and Theory for Music Education 19 (1): 208-44. https://doi.org/10.22176/act19.1.208 
particular (Bell-Robertson 2011, Partti and Karlsen 2010, Ruthmann and Marshall 2013, Veblen and Waldron in press, Waldron 2009, 2011, 2013b). Related to Wenger's CoP theory is Barrett's (2006) and Kenny's (2016) more focused communities of musical practice theory (CoMP). CoMP is derived from Wenger but was developed specifically for examining music communities. We employed Wenger's CoP theory as the "macro" framework for this research, with Kenny's CoMP theory situated within Wenger's larger CoP theory. Thus, CoMP theory functions as the "micro" framework over the course of this longitudinal study. We intend to detail the finer distinctions between CoP and CoMP in our next writings.

\section{Methodology}

Following Hine (2009, 2015), Merriam and Tisdale (2016) and the principal investigator's earlier work (2011, 2013a, 2016; Waldron and Bayley 2012; Waldron and Hopper 2014), and mindful of online ethics (Veblen and Kruse 2017), we blended qualitative research strategies of participant observation and interview with cyber ethnographic methods of observation. The Paris Port Dover Pipe Band uses MyBand as a listserve, distribution list, collaborative means for file sharing, event management, and inventory. Since this online platform stores all the band's logistics, it serves as an archived narrative text for our multi-sited case study. Data gathered from MyBand through cyber ethnographic techniques served to inform and triangulate other information. For offline data collection, we chose ethnographic method because it is the "most appropriate" research tool for researchers studying music teaching and learning in the context of transmission (Szego 2002).

Data were descriptively coded, because that is an appropriate coding method for ethnographers dealing with a wide variety of data forms-interview transcripts, field notes, journals, written Internet texts, UGC, e-mail, artifacts, and video (Saldana 2009). Descriptive coding is also useful for evaluating data collected longitudinally to assess participant changes in learning to assess visual data-digital video, Internet resources/user-generated content, YouTube videos, photographs and print material-our approach used a "holistic interpretive lens guided by the research questions." We examined and reflected on images and generated written data in the form of analytic memos to accompany the visual data (42). Analysis was thus interpretive and iterative as we identified categories and themes that emerged

Waldron, Janice, and Kari K. Veblen. 2020. Oh Canada meets Scotland the Brave: Identity, meaning, culture, and music learning in an intergenerational Canadian-Scottish pipe band. Action, Criticism, and Theory for Music Education 19 (1): 208-44. https://doi.org/10.22176/act19.1.208 
from the data. Triangulation of learning/teaching events was made possible through the comparison of participants' perspectives with observer/researchers relative to the same. Transcripts were cross-checked with one another and with observation data, archived Facebook and forum posts, and emails; member checking was incorporated into this research to ensure further trustworthiness.

We observed the Paris Port Dover Pipe Band practicing on five different occasions between 2017 and 2018. Three of these took place at the St. George Memorial Hall, St. George, Ontario, which the band rents (the town of St. George is between Paris and Port Dover); on one occasion we observed the band practicing outdoors at a home outside St. George, and we travelled to Edinburgh to document the band practicing and performing (twice) at the 2018 Royal Edinburgh Military Tattoo, where we were also granted special access to observe the PPDPB rehearsing with other bands behind the scenes while warming up for the night's Tattoo. Additionally, we observed the PPDPB at the 2017 Cambridge Highland Games and the 2018 Kincardine Scottish Festival.

We undertook five interviews: four individual and one focus group. The individual interviews were 2 to 3 hours long, and the focus group was one hour. These took place in St. George at the Memorial Hall and the local pub. Data were member-checked and triangulated with observations in the form of field notes and video. Interview transcripts were cross-checked with one another. All interviewed participants were of legal age and, when asked, requested that we use their real names, not pseudonyms. We did, however, assign pseudonyms to two participants, Nick and Robert (discussed later in the paper).

For this paper, we focus on five emergent themes: 1) identity, 2) leadership, 3) community, 4) intergenerationality, and 5) excellence (which was also intertwined with performance expectations and competition). We observed the convergence of all five themes in the Paris Port Dover Pipe Band's performance at the 2018 Royal Edinburgh Military Tattoo. This paper serves as an introduction to and a contextualization of our study, using the five surfacing themes framed with Wenger's (1998) CoP theory. A subsequent paper will consider music learning and teaching within the Pipe Band. We begin with a short biography of the Pipe Major Gordon Black.

Waldron, Janice, and Kari K. Veblen. 2020. Oh Canada meets Scotland the Brave: Identity, meaning, culture, and music learning in an intergenerational Canadian-Scottish pipe band. Action, Criticism, and Theory for Music Education 19 (1): 208-44. https://doi.org/10.22176/act19.1.208 


\section{Pipe Major Gordon Black}

Pipe Major Gordon Black is the founder of The Paris Port Dover Pipe band. At the time of this writing he is 63 years old and has been playing pipes since he was an eight-year old growing up in Ayr, Scotland. By the time he was a teenager, Gordon Black was competing both as a Grade One solo piper and as a member of the Grade One Ayr Pipe Band. As a member of the Ayr Pipe Band, he travelled to Canada in 1976 (he was 18) to perform at the Canadian National Exhibition in Toronto. Canada made a such strong impression on him that he eventually emigrated and settled in Brantford, Ontario. Black continued playing pipes and teaching privately in the Brantford area after his arrival, but he did not perform with a pipe band.

His experiences as a teenager, both playing pipes at a high level and being given the opportunity to travel to places he could not afford to go on his own, became the basis for the mandate of the Paris Port Dover Pipe Band and the band's later successes. His vision is reflected in this band as "practice" and is also what makes the PPDPB unique among Ontario pipe bands (more on this later in the paper). Gordon said:

I want to give back; I've got a lot; I've travelled the world twice playing for different [piping] organizations, and I always felt [that] when I came to Canada, well, I've got to give back. If I can give them just a fraction of what I've had in my piping career, then it's worth it.

How Gordon Black identifies himself is also insightful. We asked him what he tells people he does for a living. He replied:

Instructor. Music instructor. It's all I say... because you can't get into what I do. How do you explain that? How do you quantify what I do? I'm a teacher, I'm a bagpiper.

\section{Identity}

The CoP concept as proposed by Jean Lave and Etienne Wenger (1991) first focused on apprenticeship models for learning a trade, but then found that the relationship of master/apprentice was complex and generalizable to groups who share a profession or interests. Wenger further developed this notion to consider that learning is central to human identity. Wenger (1998) considered the below characteristics of identity in a CoP:

Waldron, Janice, and Kari K. Veblen. 2020. Oh Canada meets Scotland the Brave: Identity, meaning, culture, and music learning in an intergenerational Canadian-Scottish pipe band. Action, Criticism, and Theory for Music Education 19 (1): 208-44. https://doi.org/10.22176/act19.1.208 
- Identity as negotiated experience. We define who we are by the ways we experience ourselves through participation, as well as by the ways we and others reify ourselves.

- Identity as community membership. We define who we are by the familiar and the unfamiliar.

- Identity as learning trajectory. We define who we are by where we have been and where we are going.

- Identity as nexus of multi-membership. We define who we are by the ways we reconcile our various forms of membership into one identity.

- Identity as a relation between the local and the global. We define who we are by negotiating local ways of belonging to broader constellations and manifesting broader styles and discourses.

The components of identity formation proposed by Wenger may be seen threaded through membership in pipe and drum bands like the Paris Port Dover Pipe and Drum Band. Although this section only touches on negotiated experience and learning trajectory, the areas of multi-membership and relation between local and global in the community are discussed later in this paper.

Members of the PPDPB come to the pipe band voluntarily. The act of playing pipes and drums is a niche specialization, as these instruments draw visceral reactions with seemingly no middle ground. For some players, cultural identification may play a role; however, as displayed at the Royal Edinburgh Tattoo, identification may be dynamic, fluid, and multiple. Since pipe bands represent a diasporic heritage, there are multi-experiential aspects, colonial and hegemonic discourse.

Belonging to a collective naturally creates a group dynamic. Pipers often refer to the band as a kind of family. In a group interview after the Edinburgh experience, one member noted that the event brought people together:

As a collective all of our members are a lot closer. A couple years ago we were at a point where it was competitively focused, so we were-I wouldn't say disjointed but we weren't the family dynamic that a couple of the leadership people have been working so hard to achieve. I know that [with] everybody here, I have a personal relationship and that's what we've been aiming for-having more [of a] family dynamic and going back to where we began in the band, when it started in 2000.

When asked about how the family dynamic functioned, one player noted: "It's a bagpipe band. There's no other way to describe it. It's really weird. It's just really, ing, culture, and music learning in an intergenerational Canadian-Scottish pipe band. Action, Criticism, and Theory for Music Education 19 (1): 208-44. https://doi.org/10.22176/act19.1.208 
really weird." Another added: "We found the two loudest instruments in the world and decided to get them close. And get them as loud as possible. It doesn't really get much weirder than that."

\section{Leadership}

Interestingly, we didn't ask questions about leadership, and it did not occur to us to ask specific issues about it, either, because we intended this study's primary focus to be on music learning in pipe bands. But leadership as a theme emerged in all the participants' interviews without prompting from us and ended up being a major theme.

As a strong leader himself, Gordon Black understands that good leaders don't make themselves-people need to be mentored and then supported as they grow into leadership roles. This is also a part of "giving back" to the community and the experience he had as a youngster, and he also believes that, without growing new leaders, the organization will fail. Giving people the chance to become leaders is, in and of itself, important and a fundamental part of Black's philosophy of "giving back."

The first example of Gordon Black's influence as a mentor came from Brad Smith (who is 36 at the time of this writing), and who is in the process of taking the reins as the next Pipe Major of the PPDPB. Brad Smith has known Gordon Black since he was 14, when Black taught private pipe lessons through the local high school. 5 The high school music teacher also incorporated pipes into the music classes, allowing Smith and the other pipers to take additional music classes for credit playing the bagpipes, thus subverting the system intended only for students of the Royal Conservatory of Music. Blacks's mentorship of Smith has been gradual over the past 20 years. Brad Smith described the beginnings of his leadership:

I certainly didn't declare myself [a leader]. At a certain point, we did need to decide on a pipe major role for myself... and by the time I got the role-a few years before I noticed people coming to me-there was no announcement made or anything, but it was like. "who do we go to for these questions?" Gord's off at a meeting somewhere, so I kind of defacto started becoming "that guy" [i.e. a leader].

Waldron, Janice, and Kari K. Veblen. 2020. Oh Canada meets Scotland the Brave: Identity, meaning, culture, and music learning in an intergenerational Canadian-Scottish pipe band. Action, Criticism, and Theory for Music Education 19 (1): 208-44. https://doi.org/10.22176/act19.1.208 
Gord added that: "I don't want to overload him, because it's a huge job-it's massive [being Pipe Major]. This is all I've done for 20 odd years. So, it's a massive job to take on and [to have] me totally back off."

Although Brad Smith was ready and willing to take the reins, he was honest about both his feelings and the responsibilities which come with taking the band leadership over from the group's founder:

I'm not afraid of [Gord] or anything. But this [pipe band] is his baby; he grew this from infancy. I was fourteen when I started out with him, so I watched what happened and now ... watching the handoff slowly happening-it's terrifying to me-it's scary. Nerve-wracking when we do the tattoos. I realized this summer that I am much younger than all the other pipe majors. Gord has done so well [at being a great Pipe Major] —-what I'm so terrified of [is] screwing up [and] keeping all those things [to keep a band going] in balance.

Brad Smith, however, was also quick to note that Black "has his back":

He's there, I ['ve] got him to lean on; any second I can go to him with any thought, and I know he's got an answer for me. I don't feel any pressure from that, we get along great. I believe [we have a] friendship outside of band... is that fair to say? [He turned and asked this of Gord.]

We noticed the difference with the group dynamic when Gordon Black walked into the room before rehearsal, and Black later verified what we'd observed in terms of group dynamics at that night's band practice. This is also why Black is backing off from being at all band rehearsals, because he is paving the way for Smith to take over-so he can step aside and take a secondary role in the band:

You don't interfere, you don't show up, and you don't show off. You saw the reaction from people when I showed up tonight-it's like "holy shit, what's he doing here?” And it's not a bad thing. I don't have to be the boss. I don't have to be there anymore.

Brad Smith has continued Black's mentoring tradition of the next generation of PPDPB members, including 24-year-old lead Tenor Drummer Piper Findley, as well as others. Gordon Black explained, "Brad has got Piper to help him. He and Piper have teamed up-he's older, she's younger; she's taken a position in the band, so now they're running things together." Piper Findley confirmed this in her interview, in which she described herself as one of several

very strong female characters in the band, myself included. Whether I'm a leader type or not, it's the personalities that we have in the band-we've had a couple

Waldron, Janice, and Kari K. Veblen. 2020. Oh Canada meets Scotland the Brave: Identity, meaning, culture, and music learning in an intergenerational Canadian-Scottish pipe band. Action, Criticism, and Theory for Music Education 19 (1): 208-44. https://doi.org/10.22176/act19.1.208 
[of] stronger female personalities come up. [And] we've also been given excellent leadership [as examples].

Leadership for her, however, was a delicate balance:

We [the members in her age group of 20-somethings] were at a middle point between the upper management of the band and the adults and the group that you have here [of members in their early 20 s and late teens], so I found that being the in-between, got a little tricky, [and] got a little tiring.

She continued, explaining that: "They [the older generation] are encouraging us [because] they want us to be in that position [where we can lead as well].”

\section{Community: Local}

By the late 1990s, Gordon Black had a critical mass of private piping students from three small towns in the region, but there was no band with which they could perform, so in his words:

Eventually, [we] had to put them somewhere. These kids were coming up and there was nowhere for them to go because I wasn't associated with a band. So [a lot of] guys started to come to me-what would they do, where they would go. I said, okay, I have to find a pipe band. But there was no pipe band ... so I thought, let's form a pipe band.

He ended up starting not one, but two pipe bands: one in Paris, Ontario, and the other in Port Dover, Ontario (the towns are not too far apart geographically), also bringing in his students from the local Air Cadets as well as people from the disbanded Telephone City pipe band in nearby Brantford. He described the official launch of the two groups:

On July 1, 1998, we had a big celebration; we were in Port Dover as the Port Dover pipe band. We had a bass drum [with the Port Dover logo on it]; we all got some kilts and bag pipes... and that night we went back to Paris-we had two bass drums [one with the Paris logo and the other with the Port Dover logo], and we'd change it to the Paris pipe band-same people, same band, different bass drum. So, we kept two communities happy. [When] you live in a small area, you have to be very careful to not upset anyone. So, we brought the two communities together.

The band officially became the Paris Port Dover Pipe Band in 2003 after having someone design the band's monogram; she put the two names together in that order, thus unintentionally giving the group its official name.

Waldron, Janice, and Kari K. Veblen. 2020. Oh Canada meets Scotland the Brave: Identity, meaning, culture, and music learning in an intergenerational Canadian-Scottish pipe band. Action, Criticism, and Theory for Music Education 19 (1): 208-44. https://doi.org/10.22176/act19.1.208 


\section{Community: Provincial}

Community at the provincial and the global level emerged as themes as well. In a significant coincidence, when we observed the PPDPB Grade Four and Five ${ }^{6}$ pipe bands in June 2018, the guest instructor was Jamie Sawyer, a member of the 78th Fraser Highlanders, based in Campbellville, Ontario. He came to know Black and the band over the years through numerous Highland Games in Ontario.

The Highlanders are a suburban Grade One pipe band and are one of the few Canadian pipe bands to have won the World Piping Championships in Glasgow, Scotland. That Jamie was teaching that night was first, an example of provincial community and connections made through Highland Games and second, a lucky break for us because Jamie happily agreed to be interviewed by us in August 2019 (which we did). He also confirmed what we already suspected about the PPDPBwithout urging, he told us that a big part of his motivation for working with them was because "these guys [meaning the PPDPB] are special."

\section{Community: Global}

Community bonds and networks formed globally were also apparent at the Royal Edinburgh Military Tattoo. Andrew Harris, an experienced bagpipe instructor from New Zealand, joined the PPDPB in Scotland for the length of the Tattoo to assist the band and to perform with them. Gord and Andrew have been friends for a long time, having first met at the Basel, Switzerland Tattoo over ten years ago. They have since become good friends and now meet up every time there is a global piping event-on average, once a year.

In this clip, you'll see Andrew Harris, Gordon Black, and Assistant Drum Major Brad Smith warming up the PPDPB along with a boys' high school pipe band from Scots College, Perth, Australia. It is important to all three men that they help younger, less experienced groups wherever the PPDPB performs-part of "giving back," and that is evident in the video below.

Waldron, Janice, and Kari K. Veblen. 2020. Oh Canada meets Scotland the Brave: Identity, meaning, culture, and music learning in an intergenerational Canadian-Scottish pipe band. Action, Criticism, and Theory for Music Education 19 (1): 208-44. https://doi.org/10.22176/act19.1.208 


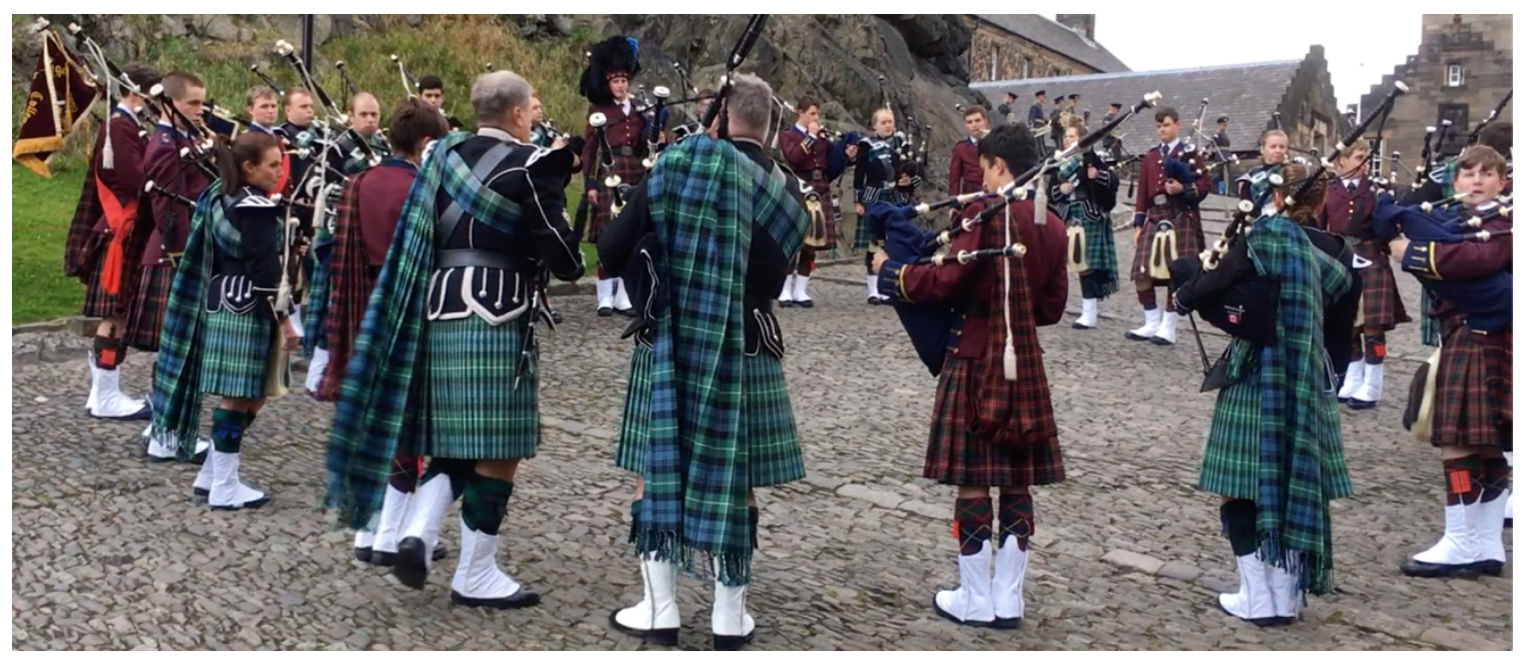

The Paris Port Dover Pipe Band warming up backstage with the Scots College Pipe Band at the 2018 Royal Edinburgh Military Tattoo. To watch the clip, go to https://youtu.be/8MBdUtRhdw4 (retrieved Sept 27, 2019)

As Brad Smith explained: "There are bands there who need the extra help-Gord and myself might go and help tune their pipes or adjust their chanters."

\section{Intergenerationality}

Although the Paris Port Dover Pipe Band's website specifically mentions teaching youth as a mandate, they welcome and teach pipes to anyone, regardless of age. The oldest member of the band is 76 , while the youngest is Nick (an alias), age nine, whose first rehearsal with the group happened to coincide with our second observation. Thus, we had the opportunity to watch the interactions of the band with the youngest, newest member. In his interview, Assistant Drum Major Brad Smith used Nick as an example when talking about how important it is to get kids on a full set of bagpipes as soon as possible. Traditionally, young pipers were only allowed to play the chanter by itself for four or five years before they were given a full set of bagpipes, but these leaders take a different approach, as Brad Smith describes here:

Let's say you're Nick's age. Nine years old. And you see a pipe band and say, "Oh I want to learn that." Then you give him [a chanter only, with] nine notes and he's got to play that [only] for four years, [so] he'll lose interest. So [with us], the development is [about] getting them on the chanter, [and] keep[ing] their interest going [until we get them on a full set]. They do need to learn the basics; they need to be able to finger. And last night, young Nick? That was his first night

Waldron, Janice, and Kari K. Veblen. 2020. Oh Canada meets Scotland the Brave: Identity, meaning, culture, and music learning in an intergenerational Canadian-Scottish pipe band. Action, Criticism, and Theory for Music Education 19 (1): 208-44. https://doi.org/10.22176/act19.1.208 
with the pipe band. He only got his [full set of bag] pipes two weeks ago [Nick had started playing chanter six months prior]. But, look at what's he's doing ... he's actually standing and playing with the band. I don't care how you play, the guys in the band love it, they think it's great. How do you feed the student? Let's get them on [the pipes] fast.

The band does more than teach kids, however. Brad Smith mentioned that, because "we bring a lot of younger people in, we [also] deal with a lot of adolescent issues. We've dealt with assaults-gender stuff. I've had kids from the pipe band stay at my house and calling their parents while we deal with issues to get them back home."

At the other end of the age spectrum were the older members, most of whom were retired. As opposed to the adolescents (not surprisingly), Gord said, "there's never any problem with them-they'll show up, even the ones who are older. The older people in the Show Band are there because they want to be there, because they want to play."

\section{Excellence and Competition}

As mentioned earlier, Canadian-Scottish Pipe Bands fall into one of two categories-those that compete and those that do not-the so-called parade bands or beer bands. Competition, as in other genres, comes with its own set of pros and cons. For those competing at a high level and who wish to achieve excellence and recognition in a codified musical practice, the pros of competition are clear, but the drawbacks are clear as well, as has already been discussed extensively in music education (O'Leary 2016, Rawlings 2019, Rohrer 2002).

Not surprisingly, the same pros and cons regarding competition in music education are also reflected in Scots-Canadian pipe bands. Those bands that are considered "good," and thus worthy of joining, compete. Bands that do not compete are thus considered "less worthy" and/or "bad" because their members often "just want to play." The latter group is looked down upon by the former and often referred to derisively as "beer bands." But for non-competition bands, there is always the question of how to attain excellence: How does the group get better to the point of being recognized as sounding good in the genre at the level at which they play (Kerr 1994, Loten 1995, Mari 2007, MacRae 2001, McKerrell 2011). Further,

Waldron, Janice, and Kari K. Veblen. 2020. Oh Canada meets Scotland the Brave: Identity, meaning, culture, and music learning in an intergenerational Canadian-Scottish pipe band. Action, Criticism, and Theory for Music Education 19 (1): 208-44. https://doi.org/10.22176/act19.1.208 
because of how individual piping competitions are regulated, competing solo pipers can cause strife within their associated Pipe Band.

Gordon Black has, however, developed a third way with the PPDPB that makes the group different and supports musical excellence regardless of venue, competing or not. First, the PPDPB as a unit consists of four different groups, all going under the banner of the PPDPB. There are two competition bands (during the years we observed there was a Grade Four and a Grade Five Band), a group which does special invited events, like the Edinburgh Royal Military Tattoo, the Basel Switzerland Tattoo, and Paul McCartney at the Air Canada Centre, and the last group, the Show Band.

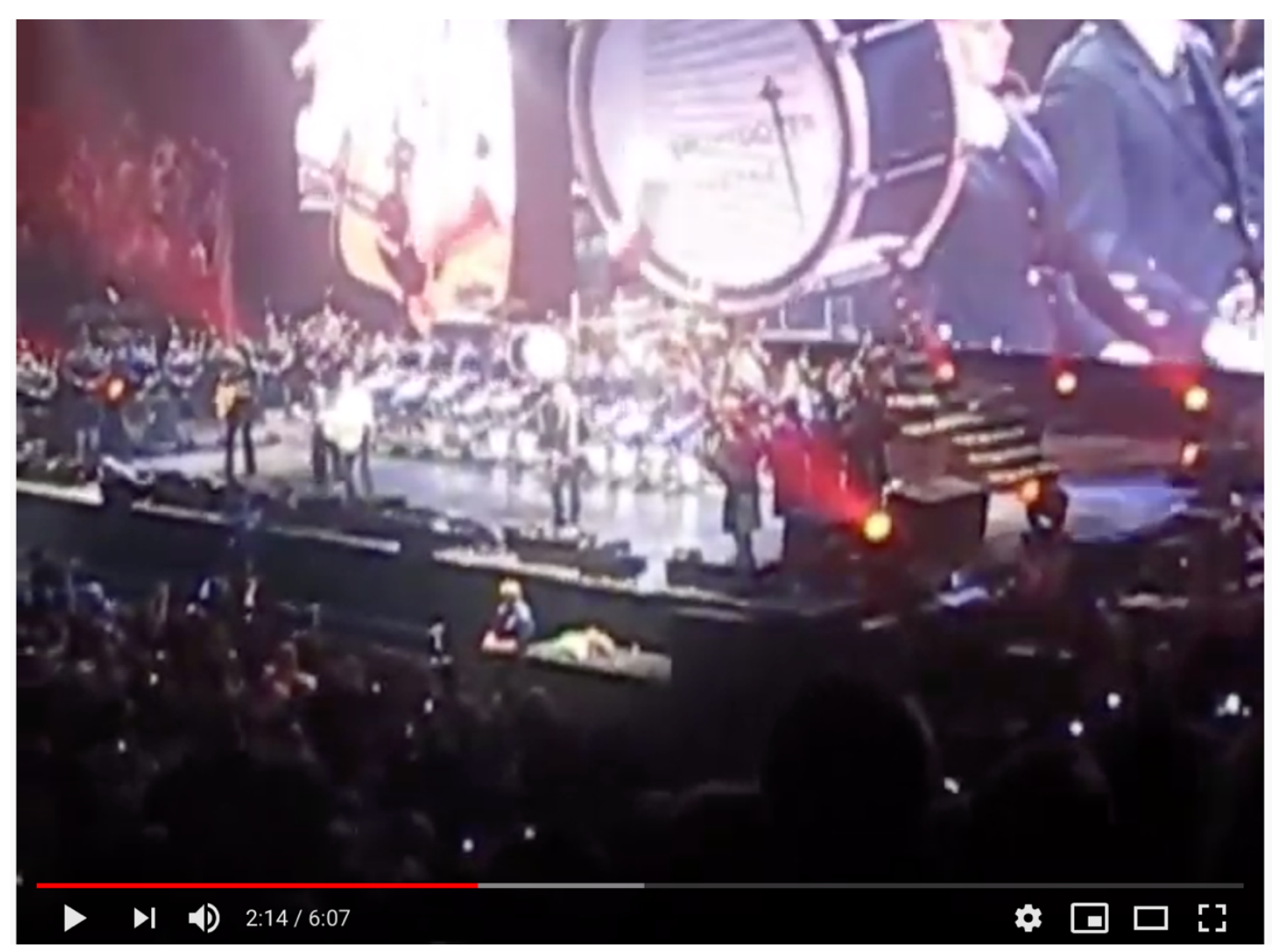

Paul McCartney and the Paris Port Dover Pipe Band at the Air Canada Centre. (Retrieved from https://youtu.be/JL35K2x7IFM, Sept 29, 2019)

Both the special event group and the Show Band are composed of members who enjoy playing but do not want to compete. It also includes members from the competition bands who want to play in both. As well as 20+ pipes and drums, the

Waldron, Janice, and Kari K. Veblen. 2020. Oh Canada meets Scotland the Brave: Identity, meaning, culture, and music learning in an intergenerational Canadian-Scottish pipe band. Action, Criticism, and Theory for Music Education 19 (1): 208-44. https://doi.org/10.22176/act19.1.208 
Show Band has additional members on keyboard, fiddles, vocals, guitar, and bass. The Show Band came about because Gordon Black wanted a place for people to perform who were not interested in competing but wanted to play well with a group that was respected as "good." Therefore, he created the Show Band, which does just that. They put on shows, big ones. We observed them in July 2017 as they were getting ready for their show at the Sanderson Centre in Brantford (the 500 hundred seat hall sold out). The big number at that night's rehearsal was a medley from "Les Miserables" arranged for pipe and rock/pop band by the band's piano player (a retired music teacher). Of the Show Band, retired member Heather Drecker said:

I think our motivation... it's different across the board, but I have a strong dedication to the band itself. It's motivations, it's ideology, [and] not necessarily that we win, or we compete, or we do the best, or that we do all these shows. I like that it includes young people, and I think asserting that and letting people know, they see a greater purpose than what I'm doing, and they want to give me the opportunity, because it ensures the longevity of the band will continue.

For those who do want to compete, there are the PPD Grade Four and Grade Five bands, but balancing competition with playing for enjoyment only is tricky, as Black explained. He described competition as:

A necessary evil-that is exactly what it is [competition]. I don't like what it does to me personally... [But] to keep a band like this going [sometimes] you have to give them something. You have to feed them. You have to give them something to work for... [but] competition is very draining, it becomes everything. It's all you do.

He further noted that:

You're not going to grow a band like ours from competition alone, but at the same time you'll lose those players if you don't allow them the opportunity to develop. We want a place for everybody, whatever level you're at. I want to be able to put you in there. The only reason I'm satisfied losing a player from our band is because we just couldn't offer them those opportunities. Ready for Grade One and good to go? We talk to players about not going TO Grade One because they're not ready, and it's like, "you're going to hurt yourself doing that." I've also had players good to go at Grade One, but they wanted to stay with us. We'll find a good spot for them. Maybe they're ready for a pipe major role, or a pipe sergeant role or an instructor role somewhere. We'll find those places for people if we can.

Gordon Black has created a space for everyone, regardless of age, playing level, or motivations, and he maintains high expectations of excellence relative to each

Waldron, Janice, and Kari K. Veblen. 2020. Oh Canada meets Scotland the Brave: Identity, meaning, culture, and music learning in an intergenerational Canadian-Scottish pipe band. Action, Criticism, and Theory for Music Education 19 (1): 208-44. https://doi.org/10.22176/act19.1.208 
group. As a whole, all of the groups are the Paris Port Dover Pipe Band. They represent, with pride, their local community to the best of their abilities, whatever those might be. To quote Black: "We meet them where they are."

This philosophy, and the community networks the band has formed combined with their reputation for excellence, was the reason the PPDPB was invited to be the Canadian representative at the 2018 Royal Edinburgh Military Tattoo. It was their third appearance, and they were told they are welcome to participate any year they want to go.

\section{The Royal Edinburgh Military Tattoo}

We observed a culmination of the five themes focused on in this paper: leadership, identity, community, intergenerationality, and excellence in the piping genre in the Paris Port Dover Pipe Band's participation and performances at the 2018 Edinburgh Tattoo. A huge draw, the Tattoo takes place every August with daily nighttime performances during the week and twice on Saturdays throughout the month. In 2018, all 25 shows of 8800 seats sold out.

We asked Lead Tenor Drummer Piper Findley, age 24, to describe her average day at the Tattoo:

There were two different kinds of typical days. [The first], our practice days for the first two weeks... we were up pretty early in the morning, drove to our practice, ran through rehearsals, [and] ran through the entire set a couple more times, had corrections made by the [Royal Military Tattoo] directors, and then we would get on a bus to go home and everybody would be pretty tired by that point. So we'd either relax all together or just go to our rooms ... [The] second kind of day were performance days, which started at four o'clock. We'd get ready, get down to the buses, go to the performance, do our performance, [and] get back to the dorm at around 12, 12:30 am. Then we'd either get ready to go out as a group or we would go and relax in our rooms, go to sleep and then we'd wake up around 11 o'clock... some of us slept a little later than that, probably closer to one... three... [laughter...]

But Findley said it was all worth it:

Going to the tattoo, you're all serving a common purpose. And everybody recognizes it, you're working towards the same goal-if we're not reaching that goal, it's the downfall of everybody. Everybody is just trying to help everybody else out, and you can't do that if you're not getting along, so just having conversations with the other bands and being open and receptive [is required].

Waldron, Janice, and Kari K. Veblen. 2020. Oh Canada meets Scotland the Brave: Identity, meaning, culture, and music learning in an intergenerational Canadian-Scottish pipe band. Action, Criticism, and Theory for Music Education 19 (1): 208-44. https://doi.org/10.22176/act19.1.208 
The 2018 Tattoo was Gord's last major event as the PPDPB's Drum Major-he is retiring from the position and passing the Drum Major's hat to Assistant Drum Major, 35-year-old Brad Smith. We asked Gord how he felt about this, his last Tattoo, as the guy in charge:

\begin{abstract}
Personally, for me [the satisfaction] was watching the full production come together and watching our guys be part of it and watch[ing] the guys grow. Watching these kids grow. Because they grew from where they came from not a wee bit, but a lot, [and] to doing this world class show in the space of a week. They came and they stood and they took all the shouting that was going on and all the criticism to all of the bands... The highlight for me was watching how our band stood alone from every other band. The other bands had problems. Like they all had sound problems, playing problems. The director of music knew you'd never have to worry about our band because we'd be bang on in sound. And they tried hard to pick holes at us but [couldn't]. . . Another highlight for me was watching our band stand behind the castle tuning up. And nobody came near us. After that first week, and into the second week, nobody came near us. They didn't have to. Because our guys were confident. And that was the band growing; it was [me] trying to let go and letting Brad do his thing-and then me standing in the background, just watching.
\end{abstract}

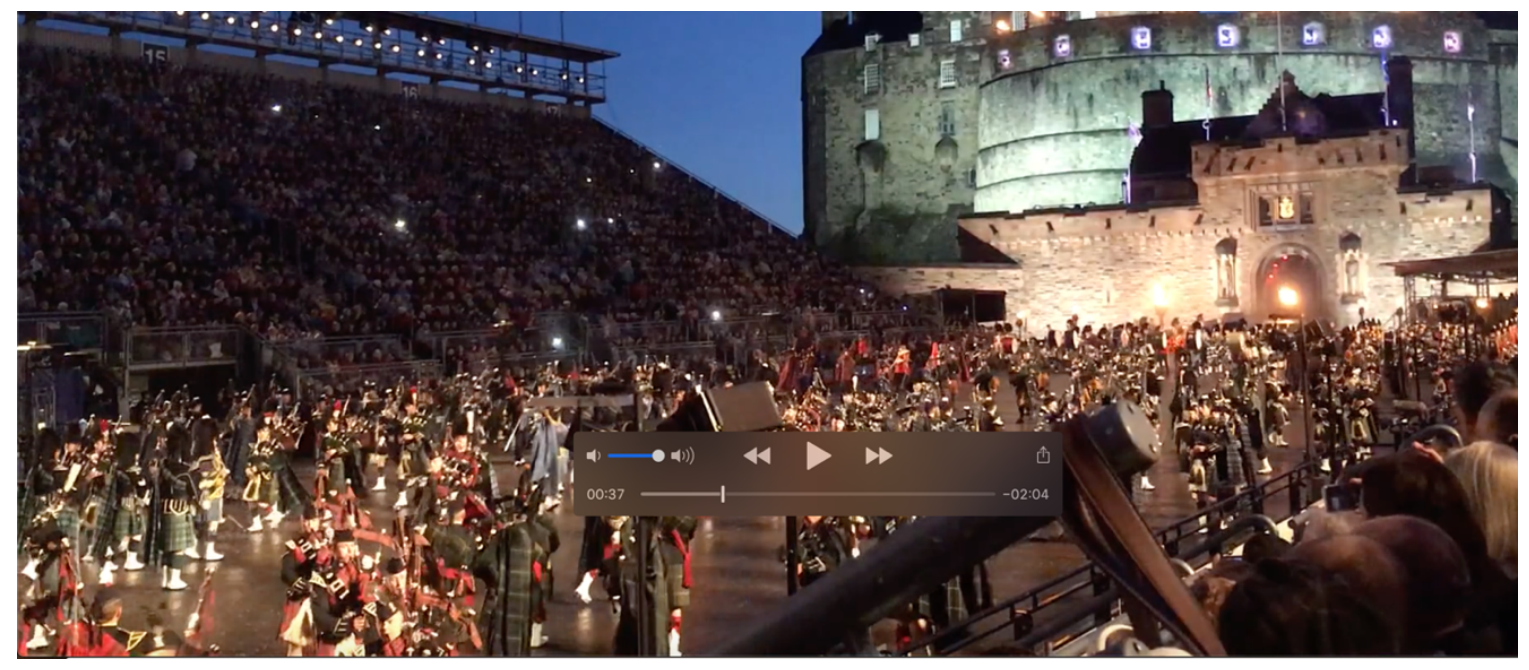

Massed Pipe Bands at the Royal Edinburgh Military Tattoo 2018 (The Paris Port Dover Pipe Band is in the left hand bottom corner above). To watch the video, go to https://youtu.be/uPBlNiPgORo (retrieved September 27, 2019)

Waldron, Janice, and Kari K. Veblen. 2020. Oh Canada meets Scotland the Brave: Identity, meaning, culture, and music learning in an intergenerational Canadian-Scottish pipe band. Action, Criticism, and Theory for Music Education 19 (1): 208-44. https://doi.org/10.22176/act19.1.208 


\section{Conclusion}

In this paper, we introduced and contextualized our study in Canadian-Scottish Pipe Band music learning in off and online settings, which is projected to proceed in five Canadian sites over a seven to ten-year timeframe. Five themes emerged from our analysis of coded data: 1) identity, 2) leadership, 3) community, 4) intergenerationality, and 5) excellence (as integrated with performance expectations and competition). Furthermore, we observed the convergence of all five themes in the Paris Port Dover Pipe Band's performance at the 2018 Royal Edinburgh Military Tattoo.

Each of the five themes is woven throughout the band experience. Identity is central, as members choose to dedicate many hours to being part of this musical entity. Membership is voluntary and open to all regardless of age, race, gender, or social class, but is dependent on willingness to learn and to participate. Leadership plays a key role; leaders and mentors guide and set the tone. Community emerges as a theme: the pipe band operates independently from formal music education systems in that music teaching and learning are done within the group, with no membership fees, while at the same time, the PPDPB intersects and collaborates with public schools among other systems. Intergenerationality creates strong bonds between band members. Finally, excellence is important to this group both in performance, competition, and in-house playing.

Results from our examination of Scottish Pipe Band music learning in off and online settings could serve as an alternative model for current music education practice, applicable to other genres, andragogy, pedagogy, and community music contexts. Research suggests that many adults do not continue playing instruments learned at school (Mantie and Tucker 2008); however, this finding is in sharp contrast to the learning and participation that takes place in Canadian SPBs.

In our subsequent papers, we will identify skills, perceptions, and knowledge that band members value as they learn musically. This knowledge could make school music education more relevant to real-world musical practices. In addition to having implications for music education practice, research, and lifelong learning, this research offers opportunities to understand the complex ways in which teaching and learning evolve, as participants negotiate learning in on and offline community contexts.

Waldron, Janice, and Kari K. Veblen. 2020. Oh Canada meets Scotland the Brave: Identity, meaning, culture, and music learning in an intergenerational Canadian-Scottish pipe band. Action, Criticism, and Theory for Music Education 19 (1): 208-44. https://doi.org/10.22176/act19.1.208 


\section{Acknowledgement}

This research is funded by the Social Sciences and Humanities Research Council of Canada.

\section{About the Authors}

Janice Waldron is an Associate Professor of Music Education at the University of Windsor; research interests include informal music learning practices, online music communities, social media and music learning, vernacular musics, adult music learning, Irish and Scottish traditional musics, and wind band conducting. Janice is published in numerous international peer-reviewed music education journals and in a variety of Oxford Handbooks and Routledge Companions. In addition to being Editor of TOPICs in Music Education, she is an Editorial Board member of the International Journal of Music Education, Action, Criticism, and Theory in Music Education, The Journal of Music, Education, and Technology, The International Journal of Popular Music Education, and Canadian Winds. Her latest in press publication is The Oxford Handbook of Social Media and Music Learning, of which she is principal editor (with Dr. Stephanie Horsley and Dr. Kari Veblen, co-editors).

Kari K. Veblen is a Professor Emeritus of music education at Western University in Canada; specialties include work on cultural perspectives, music for children, and graduate research methods. Her career spans four decades of work as an elementary public-school music teacher, community musician, faculty member at University of Wisconsin-Stevens Point, curriculum consultant to orchestras and schools, visiting scholar at University of Toronto, and research associate at University of Limerick. Veblen has served in numerous professional capacities, including the International Society for Music Education board, and as cofounder and now board member of the International Journal of Community Music. Her research interests include community music networks, lifespan music learning, traditional transmission, vernacular genres, interdisciplinary curriculum, musical play, and social media and music learning. She is the author and coauthor of five books and over 90 peer-reviewed works.

\section{References}

Barr, Deborah, Patrick Potter, Lee Van Dusen, and Jeanmarie Burke. 2005. Prevalence of problems associated with playing the Great Highland Bagpipe: Survey results and comparisons to other musicians. Medical Problems of Performing Artists (20) 4: 163-7.

Waldron, Janice, and Kari K. Veblen. 2020. Oh Canada meets Scotland the Brave: Identity, meaning, culture, and music learning in an intergenerational Canadian-Scottish pipe band. Action, Criticism, and Theory for Music Education 19 (1): 208-44. https://doi.org/10.22176/act19.1.208 
Barrett, Margaret S. 2006. Inventing songs, inventing worlds: The "genesis" of creative thought and activity in young children's lives. International Journal of Early Years Education 14 (3): 201-20. https://doi.org/10.1080/0966 9760600879920

Bayley, Jonathon, and Janice Waldron. 2019. It's never too late: Adult students and music learning in one online and offline convergent community music school. The International Journal of Music Education 38 (1): 36-51.

Baym, Nancy. 2010. Personal connections in the digital age. Cambridge, UK: Polity Press.

Beaton, James. 2011. Noting the tradition. Piping World 2011 (Fall): 44-6.

Bell-Robertson, Catherine G. 2011. Sharing emotional repertoire: A case study of an online community of practice for novice music teacher. PhD diss., University of Wisconsin-Milwaukee.

Bertoff, Rowland. 1982. Under the kilt: Variations on the Scottish-American ground. Journal of American Ethnic History 1 (2): 5-34.

Blanton, Christen J. 2016. Pathways to learning: The musical journeys of five adult fiddle players. PhD diss., University of North Carolina, Greensboro.

Bob Dunshire Bagpipe Forum, August 15, 2016. http://forums.bobdunsire.com/ forums/

Brewer, Wesley D., and David A. Rickels. 2014. A content analysis of social media interactions in the Facebook band directors group. Bulletin of the Council for Research in Music Education 201 (Summer): 7-22.

Calder, Jenni. 2003. The Scots in Canada. Edinburgh: Luath Press.

Campey, Lucille H. 1997. The regional characteristics of Scottish emigration to British North America, 1784-1854, Volumes I and II. PhD doctoral dissertation. University of Ottawa.

Canadian Bagpipe links. n.d. http://canadianbagpipelinks.info/pipe_bands.html

Cawley, Jessica. 2013. The musical enculturation of Irish traditional musicians: An ethnographic study of learning processes. PhD dissertation, University College Cork. 
City of Regina Pipe Band. n.d. http://www.crpb.org/index.php/home

Coco, Angela. 2008. Pagans online and offline: Locating community in postmodern times. Sociological Spectrum 28 (2): 510-30.

Coffman, Don D. 1996. Musical backgrounds and interests of active older adult band members. Dialogue in Instrumental Music Education 20 (1): 27-31.

Coffman, Don D. 2002. Adult education. In The new handbook of research on music teaching and learning, edited by Richard Colwell and Carol Richardson, 199-209. New York: Oxford University Press.

Coffman, Don D. 2006. Voices of experience: Interviews of adult community band members in Launceston, Tasmania, Australia. International Journal of Community Music 1 (1): 1-23.

Cohen, R. 1975. The bagpipe: The history of a musical instrument. Boston, MA: Routledge.

Columbus Doyle, Erin. 2005. "The community is the culture": Festivity, community identity and ethnicity at the Antigonish Highland Games. PhD diss., Memorial University Newfoundland.

Cope, Peter. 2005. Adult learning in traditional music. British Journal of Music Education 22 (2): 125-40.

Cresswell, Jessica. 2014. “Tatoo.” In Little Oxford dictionary of word origins. New York: Oxford University Press.

Curnow, Stuart. 2013. Standing on the shoulders of giants: The Northern Ireland piping phenomenon. Piping World 2013 (Spring): 30-35.

Czulinski, Winnie. 2004. Drone on! The high history of Celtic music. Quebec: Sound and Vision.

Dabback, William. 2007. The sociological foundations of identity and learning in the Rochester New Horizons bands. In Sociological explorations: Proceedings of the 5th international symposium on the sociology of music education, edited by Brian A. Roberts, 97-110. St. Johns: Memorial University Press.

Dabback, William. 2008. Identity formation through participation in the Rochester New Horizons Band programme. International Journal of Community Music 1 (2): 267-86.

Waldron, Janice, and Kari K. Veblen. 2020. Oh Canada meets Scotland the Brave: Identity, meaning, culture, and music learning in an intergenerational Canadian-Scottish pipe band. Action, Criticism, and Theory for Music Education 19 (1): 208-44. https://doi.org/10.22176/act19.1.208 
Dabback, William, and Janice Waldron. 2012. Circles of learning: Appalachian mountain music and issues of traditional in the 21st century. The International Journal of Community Music 5 (3): 253-64.

Dartmouth and District Pipe Band School. n.d. http://dartmouthpipeband.com /school/

Dickson, Joshua. 2009. The highland bagpipe. Burlington, VT: Ashgate.

Edinburgh Tattoo. n.d. http://www.edintattoo.co.uk

Elliott, David J. 1995. Music matters: A new philosophy of music education. NY: Oxford University Press.

Emmerson, George S. 1971. Rantin'pipe and tremblin'string: A history of Scottish dance music. Montreal: McGill-Queen's University Press.

Fantone, Gina. 2010. "You'll break your heart trying to play it like you sing it": Intermodal imagery and the transmission of Scottish classical bagpiping. Ethnmusicology 54 (3): 395-424.

Feintuch, Burt. 2004. The conditions for Cape Breton fiddle music: The social and economic setting of a regional soundscape. Ethnomusicology 48 (1): 73-104.

Folkestatd, Goran. 2006. Formal and informal learning situations or practices vs. formal and informal ways of learning. British Journal of Music Education 23 (2): $135-45$.

Forest, Timothy. 2008. Kith but not kin: The highland Scots, imperial resettlement, and the negotiating of identity on the frontiers of the British empire in the interwar years. PhD diss., University of Texas, Austin.

Fraser, Joy. 2011. A taste of Scotland? Representing and contesting Scottishness in expressive culture about haggis. PhD diss., Memorial University, Newfoundland.

Fujiwara, Aya. 2007. From Anglo-conformity to multiculturalism: The role of Scottish, Ukrainian, and Japanese ethnicity in the transformation of Canadian identity, 1919-1971. PhD diss., University of Alberta.

Gaudry, Lesley Renee. 2007. What clan are you? An exploration of heritage and ancestral tourism for Canadian Scottish descendants. PhD diss., University of Waterloo.

Waldron, Janice, and Kari K. Veblen. 2020. Oh Canada meets Scotland the Brave: Identity, meaning, culture, and music learning in an intergenerational Canadian-Scottish pipe band. Action, Criticism, and Theory for Music Education 19 (1): 208-44. https://doi.org/10.22176/act19.1.208 
Gibson, John G. 2002. Old and new world highland bagpiping. Montreal, CA: McGill-Queen's University Press.

Gibson, Sarah Katherine. 2007. The emigration of Adam Smith's ploughman: A case study of the intellectual culture of Scots emigrants to Lower Canada 17601850. PhD diss., McGill University.

Herridge, M. 1987. Scottish emigration to Canada, 1740-1850. Unpublished master's thesis, University of Texas, Arlington.

Hine, Christine. 2009. How can qualitative internet researchers define the boundaries of their projects? In Internet Inquiry: Conversations About Method, edited by Annette N. Markham, and Nancy K. Baym, 1-20. Thousand Oaks, CA: Sage.

Hine, Christine. 2000. Virtual ethnography. Thousand Oaks, CA: Sage.

Hine, Christine. 2015. Ethnography for the internet: Embedded, embodied, and everyday. New York, NY: Bloomsbury Academic.

Hinson, Andrew. 2010. Migrant Scots in a British city: Toronto's Scottish community, 1881-1911. PhD diss., University of Guelph.

Jaffurs, Sherri. 2006. The intersection of informal and formal music learning practices. International Journal of Community Music. https://www.researchgate.net/publication/255572065_THE_INTERSECTION_OF_INFORMAL_AND_FORMAL _MUSIC_LEARNING_PRACTICES.

Jenkins, Lisa Davenport. 2004. Celtic connections: "Celticism" in Scottish music. PhD diss., University of Michigan.

Jenkins, Phil. 2011. Formal and informal music educational practices. Philosophy of Music Education Review 19 (2): 179-97.

Karlsen, Sidsel. 2007. The music festival as an arena for learning: Festspel I Pite Älvdal and matters of identity. PhD diss., Luleå University of Technology.

Kear, Karen. 2011. Online and social networking communities. New York: Routledge.

Kenny, Ailbhe. 2016. Communities of musical practice. New York: Routledge. 
Kerr, Grant. 1994. Scottish pipe bands in Winnipeg: A study of ethnic voluntary associations. Unpublished master's thesis, University of Manitoba.

Kimble, Chris, and Paul Hildreth. 2004. Communities of practice: Going one step too far? http://ssrn.com/abstract $=634642$

Kruse, Nathan. 2007. Andragogy and music: Canadian and American models of music learning among adults. PhD diss., Michigan State University.

Kruse, Nathan, and Kari K. Veblen. 2012. Music teaching and learning online: Considering YouTube instructional videos. Journal of Music, Technology and Education 5 (1): 77-87.

Lave, Jean, and Etienne Wenger. 1991. Situated learning: Legitimate peripheral participation. Cambridge University Press.

Lerwick, R. W. 1980. The pipe major's handbook: A complete operator's manual for the Scottish Pipe Band. London Ontario: Scott's Highland Services Ltd.

Loten, Sarah. 1995. The aesthetics of solo bagpipe music at the Glengarry Highland Games. Unpublished master's thesis, University of Ottawa.

MacRae, Gordon. 2001. A Highland gathering: A ritual that creates, maintains, and reinforces Scottish cultural identity. Unpublished master's thesis, Carleton University.

MacDonald, Jennifer Marie. 2006. "Devil on the fiddle": The musical and social ramifications of genre transformation in Cape Breton music. Unpublished master's thesis, McGill University.

MacDonnell, Margaret. 1982. The emigrant experience: Songs of highland emigrants in North America. Toronto, ON: University of Toronto Press.

Mans, Minette. 2009. Informal learning and values. Action, Criticism, and Theory for Music Education 8 (2): 79-93. http://act.maydaygroup.org/articles/Mans8_2.pdf

Mantie, Roger, and Lynn Tucker. 2008. Does music-making have to stop upon graduation? The International Journal of Community Music 1 (2): 217-28.

Mantle, Craig Leslie. 2002. Bagpipe and limestone: The history of the 253rd Battalion (Queen's University Highlanders), C.E.F. Unpublished master's thesis, Queen's University.

Waldron, Janice, and Kari K. Veblen. 2020. Oh Canada meets Scotland the Brave: Identity, meaning, culture, and music learning in an intergenerational Canadian-Scottish pipe band. Action, Criticism, and Theory for Music Education 19 (1): 208-44. https://doi.org/10.22176/act19.1.208 
Mari, Genevieve. 2007. When the pipers play: Identity politics and Scottishness. Unpublished master's thesis, Concordia University.

Mark, Michael. 1996. Informal learning and adult music activities. The Bulletin for the Council of Research in Music Education 130: 119-22.

Mason, Cameron. 2004. Rethinking the revival and evolution of the Glengarry Scottish Highland Games: Antimodernism, commercialization, and cultural reproduction in rural eastern Ontario. PhD diss., University of Windsor.

Massed Pipe Bands at the Royal Edinburgh Military Tattoo 2018. https://youtu.be/uPBlNiP9ORo

McKerrell, Simon. 2011. Sound performing: Sound aesthetics among competitive pipers. International Review of the Aesthetics and Sociology of Music 42 (1): $165-87$.

McNabb, Heather. 1999. Montreal's Scottish community, 1835-65: A preliminary study. Unpublished master's thesis, Concordia University.

Melin, Mats H. 2014. Step dancing in Cape Breton and Scotland: Contrasting contexts and creative processes. MUSICultures 40 (1): 35-56.

Merriam, Sharan B., and Elizabeth J. Tisdale. 2016. Qualitative research: A guide to design and implementation. San Francisco CA: Jossey-Bass.

Michielse, Maarten, and Heidi Partti. 2015. Producing a meaningful difference: The significance of small creative acts in composing within online participatory remix practices. International Journal of Music Education Special Issue: Music Learning, User-generated Content, and Participatory Culture 8 (1): 27-40.

Mok, On Nei Annie. (2011). Non-formal learning: Clarification of the concept and its application in music learning. Australian Journal of Music Education, 1: 11-15.

Moulton, Paul F. 2008. Imagining Scotland in music: place, audience, and attraction. PhD diss., Florida State University.

Myers, David E. 2007. Freeing music education from schooling: Toward a lifespan perspective on music teaching and learning. The International Journal of Community Music 1 (1): 1-24.

Waldron, Janice, and Kari K. Veblen. 2020. Oh Canada meets Scotland the Brave: Identity, meaning, culture, and music learning in an intergenerational Canadian-Scottish pipe band. Action, Criticism, and Theory for Music Education 19 (1): 208-44. https://doi.org/10.22176/act19.1.208 
O'Flynn, John. 2015. Strengthening choral community: The interaction of face-toface and online activities amongst a college choir. International Journal of Music Education Special Issue: Music Learning, User-generated Content, and Participatory Culture 8 (1): 73-92.

O'Leary, Emmett James. 2016. A phenomenological investigation of competition in high school bands. Doctoral diss., Arizona State University.

Palmquist, Jane, and Gail V. Barnes. 2015. School orchestra and string teachers Facebook group: An online community of practice. International Journal of Music Education Special Issue: Music Learning, User-generated Content, and Participatory Culture 8 (1): 93-105.

Paris Port Dover Pipe and Drum Band. n.d. https://ppdpb.myband.io/page/ mandate

Paris Port Dover Pipe Band and Scots College Pipe Band backstage at the 2018 Royal Edinburgh Tattoo. n.d. https://youtu.be/8MBdUtRhdw4

Partti, Heidi, and Sidsel Karlsen. 2010. Reconceptualising musical learning: New media, identity and community in music education. Music Education Research 12 (4): 369-82.

Paul McCartney and the Paris Port Dover Pipe Band at the Air Canada Centre. n.d. https://youtu.be/JL35K2x7IFM

Pipe Band Forum. n.d. http://www.pipebandsforum.com

Rawlings, Jared R. 2019. Benefits and challenges of large-ensemble instrumental music adjudicated events: Insights from experienced music teachers. Update: Applications of Research in Music Education 37 (2): 46-53.

Rohrer, Thomas P. 2002. The debate on competition in music in the twentieth century. Update: Applications of Research in Music Education 21 (1): 38-47.

Ruthmann, S. Alex, and Savannah Marshall. 2013. Mapping research on online communities of musical practice. https://prezi.com/2erbmkqto8di/mapping -research-on-online-communities-of-musical- practice/

Salavuo, Miikka. 2006. Open and informal online communities as forums of collaborative musical activities and learning. British Journal of Music Education 23(3): 253-71.

Waldron, Janice, and Kari K. Veblen. 2020. Oh Canada meets Scotland the Brave: Identity, meaning, culture, and music learning in an intergenerational Canadian-Scottish pipe band. Action, Criticism, and Theory for Music Education 19 (1): 208-44. https://doi.org/10.22176/act19.1.208 
Salavuo, Miikka. 2008. Social media as an opportunity for pedagogical change in music education. Journal of Music, Technology and Education (1) 2: 121-36.

Saldana, Johnny. 2009. The coding manual for qualitative researchers. Thousand Oaks: Sage.

Salmon, Janet. 2014. Qualitative online interviews: Strategies, design, and skills. New York: Sage.

Seidman, Irving. 2015. Interviewing as qualitative research: A guide for researchers in the social sciences and education. New York: Teacher's College, Columbia University Press.

Sexton, Fiona. 2012. Practitioner challenges working with informal music learning pedagogies. British Journal of Music Education 29 (1): 7-11.

Shears, Barry. 2008. Dance to the piper: The highland bagpipe in Nova Scotia. Sydney N.S.: Cape Breton University Press.

Simon Fraser University Pipe Band. n.d. https://www.sfupb.comand

Smilde, Rineke. 2009. Musicians as lifelong learners: Discovery through biography. Delft: Eburon Academic Publishers.

Smith, Antonia. 2009. Uniquely suited to this place: The discourse of Scottishness in twentieth-Century English Canada. PhD diss., University of Alberta.

Sons of Scotland Pipe Band. n.d. http://www.sospb.com

Szego, C. Kati. 2002. Music transmission and learning. In The new handbook of research on music teaching and learning, Vol. 2, edited by Richard Colwell and Carol Richardson, 707-713. New York: Oxford University Press.

The Worlds. n.d. http://www.theworlds.co.uk/about/pages/default.aspx

Van Dijck, Jose. 2013. The culture of connectivity: A critical history of social media. Oxford UK: Oxford University Press.

Vance, Michael E. 2011. From Cape Breton to Vancouver Island: Studying the Scots in Canada. Immigrants and Minorities 29 (2): 175-94.

Waldron, Janice, and Kari K. Veblen. 2020. Oh Canada meets Scotland the Brave: Identity, meaning, culture, and music learning in an intergenerational Canadian-Scottish pipe band. Action, Criticism, and Theory for Music Education 19 (1): 208-44. https://doi.org/10.22176/act19.1.208 
Veblen, Kari K. 2012. Community music making: Challenging the stereotypes of traditional music education. In Critical perspectives in Canadian music education, edited by Carol A. Beynon and Kari K. Veblen, 123-34. Waterloo, ON: Wilfrid Laurier University Press.

Veblen, Kari K. 2018. Adult music learning in formal, nonformal and informal contexts. In Special needs, community music, and adult learning: An Oxford handbook of music education, Vol 4, edited by Gary McPherson and Graham Welsh, 243-56. London: Oxford University Press.

Veblen, Kari K., and Nathan B. Kruse. 2017. Researching virtual worlds: Music teaching and learning in a space of public/private domain. In The Routledge companion to music, technology \& education, edited by Andrew King, Evangelos Himonides, and S. Alex Ruthmann, 107-219. Oxford, UK: Taylor \& Francis Ltd.

Veblen, Kari K., and Nathan B. Kruse. (in press). Children's musical play in a digital era. In The Oxford handbook of social media and music learning, edited by Janice L. Waldron, Stephanie Horsley, and Kari K. Veblen. New York: Oxford University Press.

Veblen, Kari K., Nathan B. Kruse, Stephen J. Messenger, and Meredith Letain. 2018. Children's clapping games on the virtual playground. International Journal of Music Education 36 (4): 547-59.

Veblen, K. K. and J. L. Waldron, J. L. (in press). Digital sociology, music learning, and online communities of practice. In Routledge handbook of sociology of music education, edited by Ruth Wright, Geir Johansen, Panagiotis A. Kanellopoulous, and Patrick Schmidt. New York: Routledge.

Waldron, Janice. 2009. Examining the Old Time virtual music "community of practice": Informal music learning on the Internet. The Journal of Music, Education, and Technology 2 (2+3): 97-112.

Waldron, Janice. 2011. Conceptual frameworks, theoretical models, and the role of YouTube: Investigating informal music teaching and learning in online music community. The Journal of Music, Education, and Technology 4 (2+3): 189200.

Waldron, Janice, and Kari K. Veblen. 2020. Oh Canada meets Scotland the Brave: Identity, meaning, culture, and music learning in an intergenerational Canadian-Scottish pipe band. Action, Criticism, and Theory for Music Education 19 (1): 208-44. https://doi.org/10.22176/act19.1.208 
Waldron, Janice. 2012. Locating narratives in postmodern spaces: A cyber ethnographic field study of informal music learning in online community. In Personhood and music learning: Connecting perspectives and narratives, edited by Susan A. O’Neill, 72-92. Canadian Music Educators Association /Association Canadienne des Musiciens Educateurs Volume 5, Biennial Book Series, Research to Practice. Waterloo, On: Wilfred Laurier Press.

Waldron, Janice. 2013a. User-generated content, YouTube, and participatory culture on the Web: Music learning and teaching in two contrasting online communities. Music Education Research 15 (3): 257-74.

Waldron, Janice. 2013b. YouTube, fanvids, forums, vlogs and blogs: Informal music learning in convergent on and offline music community. The International Journal of Music Education 31 (1): 91-105.

Waldron, Janice. 2014. Participatory culture in online music communities: New media systems, YouTube and music learning. In Music and media infused lives: Music education in a digital age, edited by Susan A. O'Neill, 125-140. Canadian Music Educators Association/Association Canadienne des $\mathrm{Mu}-$ siciens Educateurs, Volume 5, Biennial Book Series, Research to Practice. Waterloo, On: Wilfred Laurier Press.

Waldron, Janice. 2016. An alternative model of music learning and 'Last Fun': Participatory music making in/as participatory culture in Irish traditional music. Action, Criticism, and Theory in Music Education 15 (3): 86-112.

Waldron, Janice. 2017a. Online music communities and social media. In The $O x$ ford handbook of community music, edited by Lee Higgins and Brydie Bartleet, 109-30. New York: Oxford University Press.

Waldron, Janice. 2017b. Going digitally native: The convergence of networked technologies with music teaching and learning, In The Oxford handbook of music education and technology, edited by S. Alex Ruthmann, and Roger Mantie, 475-88. New York: Oxford University Press.

Waldron, Janice. 2017c. Social networks/social media as agency in music learning and teaching. In The Routledge companion to music, technology \& education, edited by Andrew King, Evangelos Himonides, and S. Alex Ruthmann, 235-8. Oxford, UK: Taylor \& Francis Ltd.

Waldron, Janice. 2018. Old beliefs in new bottles: Questioning 2oth century assumptions about 21st century music practices. Action, Criticism, and Theory in Music Education 15 (4): 97-103.

Waldron, Janice, and Kari K. Veblen. 2020. Oh Canada meets Scotland the Brave: Identity, meaning, culture, and music learning in an intergenerational Canadian-Scottish pipe band. Action, Criticism, and Theory for Music Education 19 (1): 208-44. https://doi.org/10.22176/act19.1.208 
Waldron, Janice, and Jonathan Bayley. 2012. Music teaching and learning in the Online Academy of Irish Music: An ethnographic and cyber ethnographic field study of music, meaning, identity, and practice in community. In Proceedings of the ISME Commission for Community Music Activity, edited by Don Coffman, 62-6. CMA 30. http://issuu.com/official_isme/docs/2012_ cma_proceedings?viewMode=magazine\&mode=embed

Waldron, Janice, and Patti Hopper. 2014. Converging contexts: Music learning and teaching at the Online Academy of Irish Music's offline summer school, Liscannor, Ireland. In Conference Proceedings of the 14th ISME Commission for Community Music Activity, edited by Don D. Coffman.

Waldron, Janice, and Kari K. Veblen. 2008. The medium is the message: Cyberspace, community, and music learning. The Journal of Music, Education, and Technology 1 (2): 99-112.

Waldron, Janice, and Kari K. Veblen. 2009. Lifelong learning in Celtic community: An exploration of informal music learning and adult amateur musicians. Bulletin for the Council for Research in Music Education 180: 59-74.

Walker, Erin F. 2015. The pipe band in North America: Tradition, transformation, and transnational identity. PhD diss., University of Kentucky.

Wenger, Etienne. 1998. Communities of practice: Learning, meaning, and doing. New York: Cambridge University Press.

Wenger, Etienne, Nancy White, and John D. Smith. 2009. Digital habitats: Stewarding technology for communities. Portland, OR: CPsquare.

Waldron, Janice, and Kari K. Veblen. 2020. Oh Canada meets Scotland the Brave: Identity, meaning, culture, and music learning in an intergenerational Canadian-Scottish pipe band. Action, Criticism, and Theory for Music Education 19 (1): 208-44. https://doi.org/10.22176/act19.1.208 


\section{Appendix}

Interview questions for participants included (but were not limited to):

1) How old were you when you learned to play bagpipes and Scottish Pipe Band music?

2) Did you have opportunities to learn music in school?

3) What were/are your motivations for learning and continuing to play Scottish Pipe Band music in your local SPB?

4) Have you developed your own self-teaching style for learning SPB music (including using Internet resources such as user-generated content - YouTubes, MP3s, tune sites - and pipe band forums) and informal learning in offline contexts such as Highland Games/Scottish Festivals in addition to learning in formal instruction (classes/private lessons/rehearsals)?

5) How do/have you learn(ed) SPB music (for example, learning from notation, recordings, or YouTube videos) in formal contexts (classes/private lessons/rehearsals)?

7) Has teaching changed in the SPB genre over the last 15 years with the advent of the Internet? If so, how?

8) What does teaching, learning, and playing this music mean to you?

9) What role does competing in Highland Games/Scottish Festivals have in your SPB?

10) What issues of context, community, belonging, and identity do you associate with being a member of your Pipe Band, the greater Scottish-Canadian diaspora of Canadian SPBs, and the international community of SPBs? and,

11) What place/role does your SPB hold in your local community as well as the national and international SPB communities?

Waldron, Janice, and Kari K. Veblen. 2020. Oh Canada meets Scotland the Brave: Identity, meaning, culture, and music learning in an intergenerational Canadian-Scottish pipe band. Action, Criticism, and Theory for Music Education 19 (1): 208-44. https://doi.org/10.22176/act19.1.208 


\section{Notes}

${ }^{1}$ Recent research into formal and informal music learning in online and convergent on and offline music communities includes the following: Bayley and Waldron 2019; Blanton 2016; Cawley 2013; Dabback and Waldron 2012; O’Flynn 2015; Michielse and Parrti 2015; Palmquist and Barnes 2015; Parrti and Karlsen 2010; Salavuo 2006, 2008; Veblen and Kruse in press; Veblen and Waldron in press; Veblen, Kruse, Messenger, and Letain 2018; Waldron 2009, 2011, 2012, 2013a, 2013b, 2014, 2016, 2017a, 2017b, 2017c, 2018; Waldron and Bayley 2012; Waldron and Hopper 2014; Waldron and Veblen 2008; Webster and Brewer 2014.

2 User-generated content (UGC) refers to text, images, videos, or audio recordings that individuals post to online social media platforms.

3 See Calder 2003, Campey 1997, Forest 2008, Fraser 2011, Fujiwara 2007, Gaudry 2007, Gibson 2007, Herridge 1987, Hinson 2010, MacDonell 1982, MacRae 2001, Mason 2004, Melin 2014, Moulton 2008, Smith 2009, and Vance 2011.

4 The Royal Edinburgh Military Tattoo (edintattoo.co.uk) is an annual event begun in 1950. Held in the historic Edinburgh castle throughout August, this spectacle features military regiments, music, dance, and armed forces displays. The term tattoo as used in the military is said to be derived from an early 17th century Dutch phrase "doe den tap toe" or "close the tap". In this case, the tap was the tap on a casket of beer. The tattoo was a signal by drummers or trumpeters to alert tavern owners near garrisons to stop serving drink and for solders to return to their units. The origin of tattoo here is linguistically distinct from the term tattoo meaning a body ornamentation (Cresswell 2014).

5 Black, working with the high school music teacher, subverted the system that was intended only for Royal Conservatory students in which they received a high school music credit for taking private lessons.

${ }^{6}$ Grade one is the highest category judged in competition out of five possible grades. The rank indicates complexity and performance expectations for players and ensemble, thus grade one is considered the most complicated and exacting repertoire level.

Waldron, Janice, and Kari K. Veblen. 2020. Oh Canada meets Scotland the Brave: Identity, meaning, culture, and music learning in an intergenerational Canadian-Scottish pipe band. Action, Criticism, and Theory for Music Education 19 (1): 208-44. https://doi.org/10.22176/act19.1.208 